\title{
A New Screening Method for Antifouling Substances Using the Blue Mussel, Mytilus edulis L.
}

\author{
Akio Harada, Kanzo SaKata* and Kazuo Ina \\ The Institute of Marine Biological Science, Faculty of Agriculture, \\ Shizuoka University, Mochimune, \\ Shizuoka 422, Japan \\ * Department of Agricultural Chemistry, \\ Shizuoka University, Ohya, Shizuoka \\ 422, Japan
}

Received July 25, 1983

\begin{abstract}
A new bioassay method for antifouling substances has been developed using the blue mussel, Mytilus edulis L. This assay method allows quick evaluation of not only the repellent activity but also the toxicity of the antifouling substances against the mussel.
\end{abstract}

Marine fouling, caused by the growth of organisms such as diatoms, algae, and invertebrates on the surface of submerged objects, creates numerous important and costly economic problems. ${ }^{1)}$ Much effort have been made to tackle this problem by searching for suitable antifouling compounds. However, basically the antifouling agents are still toxic compounds like copper and organic tin compounds, ${ }^{2)}$ etc.

Hitherto, antifouling compounds have been screened by the submergence method, which is time-consuming. Although, a few time-saving procedures have been developed, ${ }^{3)}$ they are all based on toxic compounds.

We have recently developed a new bioassay method for screening antifouling substances using the blue mussel, which causes serious fouling problems, especially in the cooling systems of power plants. This new assay method has the following advantages.

(1) The blue mussel can be obtained easily from tidal wharfs throughout the year. (2) They are active even in winter and so research can be conducted all through the year. (3) It is a fast and simple assay technique to screen for compounds with less or no toxicity but which have repellent activity.

This paper deals with the screening method and the preliminary results with some authentic chemicals and plant extracts.

\section{MATERIALS AND METHODS}

Test organisms. The blue mussels, Mytilus edulis L. (Japanese name, "Murasaki Igai," $10 \sim 30 \mathrm{~mm}$ in shell length) were collected from the tidal warf at the Mochimune fishing harbour in Shizuoka and maintained in an aquarium with running sea-water for a month before the experiments.

Preparation for the repellent assay. A commercially available asbestos plate $(30 \times 50 \times 0.5 \mathrm{~cm})$ was cleaned with tap water and dried. On the plate, sample zones $(5 \mathrm{~cm}$ in diameter) were drawn with a compass, a few centimeters apart.

The sample zone was soaked with the sample dissolved in about one $\mathrm{ml}$ of volatile solvent using a defatted-cotton ball. After the solvent evaporated, a test mussel (20 $30 \mathrm{~mm}$ in shell length) was fixed at the center of the zone with a piece of rubber $(5 \times 5 \times 5 \mathrm{~mm})$ made of a rubber stopper and cyano-acrylate adhesive ("Aronalfa," Toa Gosei Kagaku Co., Ltd.) as shown in Fig. 1.

Repellent activity: The assay plate, prepared as above, was set at the bottom of an aquarium with running seawater (ca. 3.0 liters/min) and left overnight. The mussels tried to fix themselves on the plate by attaching many byssuses (usually $10 \sim 30$ ) beneath themselves (within the sample zone), in non-active sample zones. However, if the sample was active, the mussels stretched their byssuses beyond the zone (Fig. 1). Mussels which secreted six or 


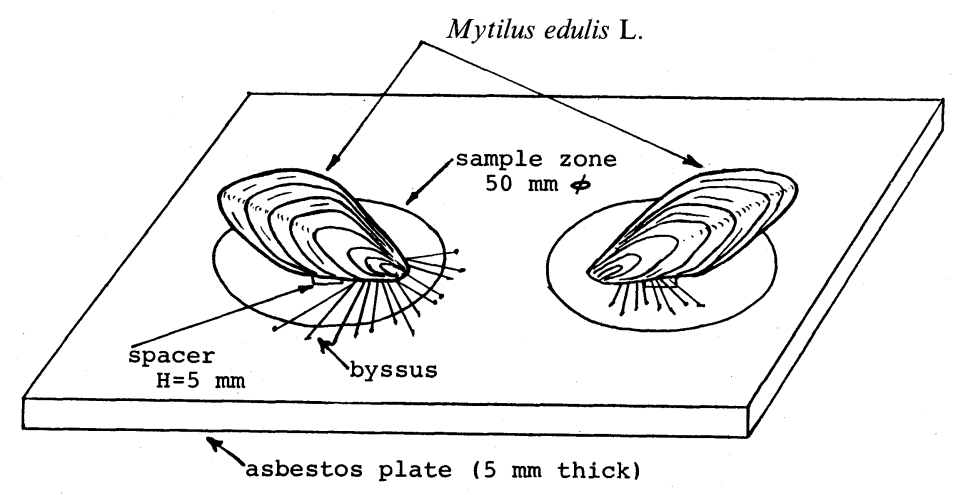

FIG. 1. Diagramatic View of the Assay Plate.

Left: An active sample is in the sample zone. All byssuses are fixed outside the zone. Right: No/inactive sample in the zone. The test mussel, Mytilus edulis L., attaches it to the board by fixing byssuses just beneath itself (inside the sample zone).

Table I. Estimation of Repellent Activity

\begin{tabular}{rc}
\hline Point & $\begin{array}{c}\text { Ratio (number of byssuses fixed } \\
\text { outside the sample zone/ } \\
\text { total number of byssuses) }\end{array}$ \\
+1 & $\geqq 2 / 3$ \\
0 & $1 / 3 \sim 2 / 3$ \\
-1 & $\leqq 1 / 3$ \\
\hline
\end{tabular}

\begin{tabular}{|c|c|c|c|}
\hline \multicolumn{3}{|c|}{ Points of each mussel tested } & \multirow{2}{*}{$\begin{array}{l}\text { Repellent activity } \\
\text { (total points) }\end{array}$} \\
\hline 1 & 2 & 3 & \\
\hline+1 & +1 & +1 & \multirow{4}{*}{$+(1 \sim 3)$} \\
\hline+1 & +1 & +1 & \\
\hline+1 & +1 & -1 & \\
\hline+1 & 0 & 0 & \\
\hline+1 & 0 & -1 & \multirow{2}{*}{$\pm(0)$} \\
\hline 0 & 0 & 0 & \\
\hline-1 & 0 & 0 & \multirow{4}{*}{$-(-1 \sim-3)$} \\
\hline-1 & -1 & +1 & \\
\hline-1 & -1 & 0 & \\
\hline-1 & -1 & -1 & \\
\hline
\end{tabular}

more byssuses were evaluated for the repellent activity.

The number of byssuses produced by each mussel was counted to calculate the ratio of the number of the byssuses stretched beyond the sample zone to the total number of the secreted byssuses. Ratios above $2 / 3$, between $2 / 3$ and $1 / 3$, and less than $1 / 3$ were awarded $+1,0$, and -1 points, respectively. The tests were repeated thrice. The repellent activity of each chemical was evaluated based on the total points as: $1 \sim 3,+; 0, \pm$; $-1 \sim-3,-($ Table I). Sample evaluated as \pm were tested again.

Toxicity test. The chemical was dissolved in $250 \mathrm{ml}$ of sea-water in a $500 \mathrm{ml}$ beaker. Water-insoluble chemicals were first dissolved in one $\mathrm{ml}$ of dimethyl sulfoxide and then made up to $250 \mathrm{ml}$ with sea-water. Twenty individual mussels ( $c a .10 \mathrm{~mm}$ in shell length) were introduced into each test solution. After $2 \mathrm{hr}$, they were taken out of the test solution, washed with filtered sea-water and placed separately in a petri dish $(18 \times 4 \mathrm{~cm})$. The petri dish was then placed at the bottom of an aquarium ( $c a .200$ liters, $30 \mathrm{~cm}$ in depth) with running sea-water (3.0 liters $/ \mathrm{min})$. After $20 \mathrm{hrs}$, the number of mussels which were alive but secreted no byssus and those that were dead with opened shells were counted to evaluate $\mathrm{ED}_{50}$ (the concentration at which half of the test mussels secreted no byssus) and $\mathrm{LD}_{50}$ (the concentration at which half of the mussels were dead), respectively.

Screening plant extracts for repellent activity. Plant materials, air-dried for $7 \sim 10$ days $(c a .10 \sim 30 \mathrm{~g}$ ), were soaked in methanol or benzene for 10 days. The extracts were then evaporated to dryness. The residue $(50 \mathrm{mg})$ was dissolved in a volatile solvent such as methanol or acetone and applied to the sample zone as described above.

\section{RESULTS AND DISCUSSION}

\section{Repellent activity of authentic antifouling chemicals}

Copper compounds have been used for a long time as antifouling substances and recently organo-tin derivatives have been found to be extremely effective. ${ }^{2)}$ The latter are mainly used for the protection of immersed objects against fouling. ${ }^{4)}$ 
Table II. RePellent ACtivity OF Standard Samples

\begin{tabular}{ccc}
\hline $\begin{array}{c}\text { Sample amount } \\
(\mathrm{mg} / \text { zone })\end{array}$ & $\mathrm{CuSO}_{4} \cdot 5 \mathrm{H}_{2} \mathrm{O}(\mathbf{1})$ & $\mathrm{TPTA}^{a}(\mathbf{2})$ \\
\hline 150 & + & \\
100 & + & \\
75 & + & \\
50 & + & \\
25 & + & $\mathrm{t}^{b}$ \\
15 & + & $\mathrm{t}$ \\
10 & \pm & $\mathrm{t}$ \\
5 & - & $\mathrm{t}$ \\
2 & - & $\mathrm{t}$ \\
1 & - & $\mathrm{t}$ \\
0.5 & & $\mathrm{t}$ \\
0.2 & & - \\
0.1 & & \pm \\
0.05 & & \pm \\
0.02 & & \pm \\
0.01 & & - \\
0.005 & & \\
\hline
\end{tabular}

a TPTA: Triphenyltin acetate.

$b$ t: toxicity.

We chose two chemicals, cuprous sulfate (1) and triphenyltin acetate (2), conventionally used as standard antifouling substances in submerged assay procedure for antifouling compounds.

Table II shows the repellent activity of the compounds. At more than $15 \mathrm{mg} /$ zone 1 showed strong repellent activity but was inactive at less than $5 \mathrm{mg} /$ zone. The activity was evaluated as, \pm+ , and - for $10(0.51$ $\left.\mathrm{mg} / \mathrm{cm}^{2}\right)$, more than 15 , and less than $5 \mathrm{mg} /$ zone, respectively.

In the case of 2 the test mussels secreted extremely few byssuses at more than $0.2 \mathrm{mg}$ / zone and the estimation of repellent activity was difficult. Even at lower concentrations the repellent activity could not be evaluated clearly. This can be attributed to its toxicity. The antifouling activity of both the compounds are probably basically different.

Usually, the blue mussel extends its foot on the surface of the plate and searches for a good spot to fix the byssuses. The mussel presses the tip of its foot over the spot for a few minutes and secretes byssuses from its byssus-gland
TABle III. Toxicity of Standard Antifouling Substances

\begin{tabular}{|c|c|c|c|c|}
\hline \multirow{2}{*}{$\begin{array}{l}\text { Conc. } \\
\text { (ppm) }\end{array}$} & \multicolumn{2}{|c|}{$\mathrm{CuSO}_{4} \cdot 5 \mathrm{H}_{2} \mathrm{O}(\mathbf{1})$} & \multicolumn{2}{|c|}{ TPTA $^{a}(2)$} \\
\hline & $E^{b}(\%)$ & $D^{c}(\%)$ & E $(\%)$ & $D(\%)$ \\
\hline 750 & $85^{d}$ & 72.5 & & \\
\hline 600 & 85 & 75 & & \\
\hline 500 & 90 & 67.5 & & \\
\hline 400 & 30 & 17.5 & & \\
\hline 250 & 7.5 & 0.5 & & \\
\hline 50 & & & 92.5 & 75 \\
\hline 25 & & & 82.5 & 55 \\
\hline 10 & & & 55 & 25 \\
\hline 5 & & & 23.5 & 17.5 \\
\hline 2.5 & & & 22.5 & 2.5 \\
\hline 1.0 & & & 30 & 0 \\
\hline $\begin{array}{ll}a & \text { Trip } \\
b & \text { E: } 1 \\
& \text { byss } \\
c & \text { D. }\end{array}$ & \multicolumn{4}{|c|}{$\begin{array}{l}\text { E: percentage of the mussels which secreted no } \\
\text { byssus. }\end{array}$} \\
\hline \multicolumn{5}{|c|}{$\begin{array}{l}\text { Twenty individual test animals }(10 \mathrm{~mm} \text { in shell } \\
\text { length) were used. Values are the mean of dupli- } \\
\text { cate tests. }\end{array}$} \\
\hline
\end{tabular}

and withdraws its foot into its shell, thus attaching the byssuses on the surface.

Cuprous sulfate (1) permitted the mussels to secrete byssuses but inhibited their attachment to the surface.

In case of $\mathbf{2}$ the test animal withdrew its foot into its shell as soon as its tip touched the sample zone and did not extend its foot for a while. Triphenyltin acetate (2) probably inhibited the secretion of byssuses because of its toxicity.

Both compounds 1 and 2 were less soluble in sea-water. The test plate was placed in an aquarium with running sea-water (3.0 liters/min). Thus the possibility of the chemical dissolving in sea-water from the sample zone was excluded. All the test mussels secreted byssuses normally after having been transferred into an aquarium.

Based on this new bioassay method not only the repellent activity but also the toxicity of each chemical could be judged exactly.

\section{Evaluation of toxicity}

To evaluate the toxicity of the antifouling 
Table IV. Repellent Activity of Plant Extracis on the Blue Mussel

\begin{tabular}{|c|c|c|}
\hline Plant (Japanese name) & $\begin{array}{l}\text { Sample amount } \\
\text { (mg/zone) }\end{array}$ & Activity \\
\hline \multicolumn{3}{|l|}{${ }^{\circ}$ Urticaceae } \\
\hline Boehmeria biloba Wedd. ("Raseitaso") & 50 & \pm \\
\hline \multicolumn{3}{|l|}{${ }^{\circ}$ Pittosporaceae } \\
\hline Pittosporum tobira Ait. (“Tobera”) & 50 & + \\
\hline \multicolumn{3}{|l|}{${ }^{\circ}$ Leguminoaceae } \\
\hline Pueraria thunbergiana Benth. (“Kuzu”) & 50 & - \\
\hline \multicolumn{3}{|l|}{${ }^{\circ}$ Euphorbiaceae } \\
\hline Acalypha australis L. ("Enokigusa") & 50 & - \\
\hline \multicolumn{3}{|l|}{${ }^{\circ}$ Vitaceae } \\
\hline Cayratia japonica Gagn. ("Yabukarashi”) & 50 & \pm \\
\hline Ampelopsis brevipedunculata Trautv. ("Nobudo") & 50 & - \\
\hline \multicolumn{3}{|l|}{${ }^{\circ}$ Cucurbitaceae } \\
\hline Trichosanthes cucumeroides Maxim. (“Karasu Uri”) & 50 & - \\
\hline \multicolumn{3}{|l|}{${ }^{\circ}$ Compositae } \\
\hline Xanthium strumarium L. (“Onamomi”) & 50 & + \\
\hline Artemisia vulgaris L. var. indica Maxim ("Yomogi") & 50 & + \\
\hline \multicolumn{3}{|l|}{${ }^{\circ}$ Gramineae } \\
\hline Coix lachryma-jobi L. ("Jyuzudama") & 50 & + \\
\hline $\mathrm{CuSO}_{4} \cdot 5 \mathrm{H}_{2} \mathrm{O}$ & 15 & + \\
\hline
\end{tabular}

compounds, a similar bioassay procedure using the mussel was adopted. Table III summarizes the results of the test.

$\mathrm{ED}_{50}$ of 1 was between 400 and $500 \mathrm{ppm}$ and that of 2 about $10 \mathrm{ppm}$. $\mathrm{LD}_{50}$ of 1 and 2 were $400 \sim 500 \mathrm{ppm}$ and $20 \sim 25 \mathrm{ppm}$, respectively. Triphenyltin acetate (2) is thus concluded to be more than ten times toxic than 1. These results confirm the toxicity of $\mathbf{2}$ in the repellent activity test mentioned above.

\section{Repellent activity of plant extracts}

Extracts of ten species of terrestrial plants (stems and leaves) were subjected to screening at $50 \mathrm{mg} /$ zone. Four species proved to be active (Table IV). However, none of them were toxic. In each case, $\mathbf{1}$ (15 mg/zone) was used as the standard.

This assay technique proved suitable for screening naturally occurring antifouling compounds. Application of this assay procedure to screen a variety of plant extracts and the isolation and structural elucidation of their active principles are in progress.

\section{REFERENCES}

1) T. Kajiwara and R. Hirano, "Kaiyogaku Koza," Vol. 9, ed. by M. Yamamoto, Tokyo University Press, Tokyo, 1973, p. 185.

2) C. J. Evans and P. J. Smith, J. Oil Colour Chem. Assoc., 58, 160 (1975).

3) S. Mawatari and Y. Kitamura, Shigen Kagaku Kenkyusho Iho, 73, 68 (1970); T. Miyauchi, Toso to Toryo, 217, 29 (1972); T. Miyauchi, ibid., 243, 49 (1974); T. Miyauchi, ibid., 260, 53 (1975); K. Ohta, H. Matsumoto and T. Nawamaki, Agric. Biol. Chem., 42, 1491 (1978); T. Lovegrove, Int. Biodeterior. Bull., 14, 6 (1978).

4) J. S. Thayer, J. Chem. Educ., 764 (1981). 